\title{
Locally Advanced Soft Tissue Sarcoma, Excluding Liposarcoma
}

National Cancer Institute

\section{Source}

National Cancer Institute. Locally Advanced Soft Tissue Sarcoma, Excluding Liposarcoma. NCI Thesaurus. Code C153371.

A finding indicating that a soft tissue sarcoma other than liposarcoma has spread from its original site of growth to nearby tissues or lymph nodes. 